\title{
Dispassion as an Ethical IDEAL
}

\author{
JEREMIAH CAREY \\ Siena College
}

\begin{abstract}
The concept of dispassion has been an important part of many different ethical traditions, and yet it has received very little direct attention from moral philosophers. In this paper, I try to give an account of the ethical ideal of dispassion, with a particular focus on Buddhism, Stoicism, and Eastern Christianity. I try to show that there is a common core shared between these otherwise very different traditions, and that it can be expressed in contemporary and not explicitly theological or religious terms. What emerges is an attractive understanding of the ethical life worthy of more investigation.
\end{abstract}

$\mathrm{T}$ HE concept of dispassion has been an important part of many different ethical traditions. Almost all of these traditions also have some emphasis on related concepts like detachment, mindfulness, and tranquility, and on practices like meditation, prayer, or contemplation. These notions are probably most readily connected by many of us with Buddhism, thanks no doubt in part to the attractions of Zen to the American counter-culture of the 1950s and '6os, the popularity and charisma of the current Dalai Lama, and the rise of positive psychology, with its consistent interest in mindfulness and meditation. But they are also present in Hinduism, and to a lesser (or at least less obvious) extent in Daoism and Confucianism. Further to the west, they were an important part of Stoic and Christian thinking about virtue, especially in the Christian spirituality that developed in the eastern part of the late Roman empire and which continues in today's Eastern Orthodox Church. ${ }^{1}$

In spite of this diverse and venerable pedigree, the idea of dispassion as an ethical ideal has received almost no attention from philosophers in the west,

1. The primary source for my discussion of the notion of dispassion in Eastern Orthodox spirituality is the Philokalia, an important collection of texts written between the $4^{\text {th }}$ and $15^{\text {th }}$ centuries and compiled in the $18^{\text {th }}$ at Mount Athos, a monastery peninsula in northeast Greece. This text is, in my opinion, a treasure trove of moral-psychological wisdom that more philosophers would do well to study.

Contact: Jeremiah Carey <jeremiah.a.carey@gmail.com> 
outside of specialists in ancient or Asian philosophy. ${ }^{2}$ I offer this as an attempted beginning. My main goal is to give a conception of dispassion as an ideal that is both faithful in broad outline to the conceptions of the various traditions mentioned above, and yet which can be understood apart from some of their particular trappings and can still be coherent and appealing for those of us interested in living a good life today.

For reasons that will be discussed in the next section, the concept of dispassion is not one that is readily intelligible as an ideal to modern minds, and because of this, I think we have no choice but to look to the ancient traditions for guidance. Three in particular that have developed and accessible accounts of dispassion as such are Buddhism, Stoicism, and the spirituality of eastern Christianity. These three will appear most often in my positive reconstruction.

Obviously, a full treatment of all three is beyond the scope of a single paper, especially given the difficulties of responsible comparative philosophy. Since I am most familiar with the latter two traditions and their foundations in Greek philosophy, and I expect many of my readers will be as well, I'll primarily focus on them, with perhaps some eventual favor being shown to the Orthodox Christian tradition. Nevertheless, as mentioned above, part of my goal is to show that, despite disagreement in some details, these otherwise diverse traditions can be seen as sharing a family resemblance that relates to a distinctive insight into moral life.

My procedure in what follows, then, will be to appeal mostly to the Stoic and eastern Christian conceptions in my exposition, but also to point to very strong prima facie similarities in Buddhist tradition and practice. Occasionally, and mostly in footnotes, I will also quote from other traditions that seem to show the same basic commitments. I will also occasionally relate the themes that emerge to more contemporary work. Given the aims of the paper, the discussion will proceed at a somewhat high level of abstraction; but, as will be seen, one of the advantages of an ethics of dispassion is the unity that it brings to several different ethical phenomena, and I want to bring this out.

What follows will have three main parts. In the first, I will clear up some of the misconceptions about dispassion that I think make even beginning to appreciate it as an ethical ideal difficult. In the second, I will give a positive account of what dispassion is as involving two parts: gaining control of and moderating certain "natural" passions so that they function in accord with the requirements of a virtuous life, and careful attention to one's inner life in order to eliminate or render inert certain other, "unnatural" passions. In the third section, I will comment on the appeal of dispassion as an ethical ideal.

2. There are surprisingly few focused treatments even within the study of the history of philosophy and comparative philosophy. The few I was able to find can almost all be found in the references here. The lone treatment I know that tries to recommend it as a standalone ethical ideal (as I aim in part to do here) is Marks (1995).

Ergo $\cdot$ vol. 5, no. 24 2018 


\section{Apatheia and Apathy}

There are no doubt many reasons that the notion of dispassion has come to lose whatever appeal it had for us even in the west. One certainly has to do with the fact that a conception of the passions itself has basically disappeared for us, replaced by the concepts of desire and emotion, neither of which quite maps onto the earlier notion of the passions. ${ }^{3}$ Whereas we might still be able (vaguely) to make sense of aiming to be dispassionate as a positive goal, or talk about "carnal or evil passions," aiming to be unemotional doesn't have anything like the same feel, nor does it seem to make much sense to talk of "carnal emotions."

On the other hand, by some inversion of the concepts, to "have passion for something" is often used in the sense of having some enduring commitment or active interest, whereas the origin for the word "dispassion", the Greek apatheia, has become "apathy", which is used to pick out a sort of unfeeling lack of interest in anything. But of course, the word "passion" is closely related to the concept of passivity, so that having dispassion in the original sense really meant being in some way distinctively active, the opposite of apathy. To further counter any idea that dispassion involves what we would call apathy, consider that the eighth-century Christian monk St. Peter of Damascus includes on his list of passions dullness, idleness, sluggishness, enervation, inattentiveness, indifference, and insensitivity (Palmer, Sherrard, \& Ware 1979-1995: Vol. 3, 205). Or consider acedia, sometimes referred to as the "noon day demon," a type of torpor or depression. According to the early monks of the Egyptian desert, who first wrote at length on this vice, the person who can't seem to get himself to focus on or care about anything is not being dispassionate, but is actually caught in the grip of a problematic passion. His problem is not that he lacks passion, but that he finds himself passive with respect to his own mental life, unable to do what he knows he should, attached to inertia, inactivity, and ease.

I take it that this is enough to show that dispassion is not the same as our apathy, since the various symptoms which make up what we call apathy were typically identified as passions themselves. Another, perhaps related, worry abounds. This is the idea that dispassion requires a complete elimination or eradication of desire or emotion. This objection is most often raised at the popular level against Stoicism and Buddhism, but it also shows up in more serious contexts, often with defenders of each tradition accusing the others of not giving the emotions their due. For example, in a treatment of the Eastern Christian

3. For a discussion of the difference between the current (philosopher's) concept of desire and how it was used to pick out only one of many passions in the modern period, see Baier (1986). For a brief history of the replacement of the passions with the emotions, see Dixon (2011). For the most part, in what follows the passions (in the non-technical sense) can be thought of broadly as the class of affective states that includes both emotions and felt desires. 
understanding of dispassion, Orthodox priest and theologian Dumitru Staniloae contrasts Christian dispassion, closely connected with love, with "Buddhist apathy" (Staniloae 2003: 189). In defense of the Buddhist understanding of compassion, Chris Frakes contrasts it with the "Stoic eradication of the emotions" (Frakes 2007: 119). David Wong argues that the Daoist notion of detachment as "resilience" is better than the Stoic and Buddhist accounts, both of which involve the complete "extirpation" of grief (Wong 2006). And so on.

While each of these traditions do differ with one another on many (no doubt important) details, it is far too simplistic to say of any of them that they involve anything like a complete rejection of emotion or desire. The Four Noble Truths of Buddhism famously connect suffering with "desire," for example, but this is a distinctive use of that term. At the very least, as Walter T. Stace points out, this can't be desire in the very broad sense in which Western philosophers use the word - for the Buddha ate, walked around, taught, and did many other things, all of which implicate desire in the most common philosophical sense (Stace 1952). And, of course, we have to be able to fit together Buddhist non-attachment with its well-known emphasis on compassion. Compassion is especially emphasized in the Mahayana form of Buddhism, but it is also one of the "Four Divine States" of the Pali Canon, which also includes loving-kindness towards all and altruistic joy in the accomplishments and happiness of all sentient beings. ${ }^{4}$

Similarly, the great Daoist philosopher Zhuangzi praises equanimity and detachment, but also weeps at his wife's death, and doesn't see himself as having thereby done anything problematic. ${ }^{5}$ Though the Stoics emphasized dispassion (apatheia), this couldn't mean a complete "eradication of the emotions," since they also said that the sage will still have the "good feelings" (eupatheiai) of watchfulness, wish, and joy. ${ }^{6}$ And I've already mentioned the connection, if not identification, between love and dispassion in the eastern Christian tradition. St. Maximus the Confessor, for example, says that "dispassion engenders love" while at the same time describing love as a "blessed passion."7

4. For a helpful overview of some of the main virtues in Buddhism, see Davis (2014).

5. On this episode, see Wong (2006) and Olberding (2007). For the Confucian account of equanimity and how it allows for emotion involvement, see Shun (2014). For somewhat similar though more extreme advice on handling the death of loved ones, see Epictetus Enchiridion 3.

6. On the tensions involved here and their legacy in medieval thought, see King (2012). In contrast with my approach, Sorabji (2000) insists both on translating "passion" as "emotion", and that the Stoics did advocate complete eradication of the emotions. However, once we allow for the eupatheiai and understand exactly how the Stoics conceived of the passions, I think it is hard to escape the thought that "passion" was something of a technical term, and not something which overlaps well with our "emotion". For this reason, it is perhaps a blessing that we no longer have any real concept of the passions, so that we can reintroduce them in just this technical way.

7. Perhaps an even more surprising juxtaposition can be found in the later ( $10^{\text {th }}$ century) St. Symeon the New Theologian: "As many as possess dispassion love it and are loved exceedingly 
The foregoing is, I hope, sufficient to dispel the myth that any of these great ethical traditions advocates either anything like what we would call apathy, or a blanket disapproval of desire or emotion. The point of this brief survey has not been to settle any interpretive debates or give a positive account, but to show that dispassion as an ethical ideal cannot be dismissed as simplistically as it often has been. But it also seems to present a clear problem for any positive understanding of dispassion: If it doesn't involve complete lack of passion, then what does it involve? And does it deserve to be called "dispassion"? It is to these questions that I will turn next.

\section{What is Dispassion?}

The three traditions I'll be focusing on, especially in Section 2.2 below, all explicitly accept an ideal of dispassion. Nevertheless, it seems to me that the exact nature of that ideal has been undertheorized even within the published philosophical work on those traditions, and that very little comparative work on the concept has been done. Since my main goal is to come up with a general account of dispassion that can be understood in contemporary terms, there are two aims that will guide this section. The first is to extract from these traditions a common basic structure to the ideal of dispassion, while also noting some of the main differences in detail. The second is to highlight along the way what seem to me some of the noteworthy observations that emerge about the ethical life and briefly relate them to more recent philosophical work. My hope is that this will make the conception more understandable and will also do something to indicate its appeal (about which I say more in the third section).

In short, the ethical ideal of dispassion, as I think it best understood, involves two parts which are shared by all the traditions. The first has to do with bringing certain passions into conformity with reason or nature. This is coming to have affective responses appropriate to whatever situation one happens to be in, having the emotions and desires that are characteristic of virtue. The second involves an attempt to eliminate as far as possible, or anyways to do constant battle with, certain other passions which are always against reason or nature. As will be seen, this has a lot to do with an ability to control one's attention. I'll talk about each of these parts in turn. Since the second is the more distinctive aspect, I'll spend more time on it.

by it. They talk about it without tiring, are on fire with longing for it, and so are rendered by it still more dispassionate" (Symeon the New Theologian 1995: Vol. 2, 12). 


\subsection{Dispassion and Virtue}

Virtue ethics is often contrasted with deontology and consequentialism in terms of a distinction between "agent-centered" and "act-centered" theories. Whereas the latter are primarily concerned with what makes actions right or wrong, the former are primarily concerned with what it is to be a good person. Because of this difference in emphasis, it's also the case that virtue ethics is typically more concerned with the emotions and desires of the agent than other theories. Utilitarianism, for example, tells us which action to do, but it is relatively silent on what states of mind we should have when acting. Virtue ethics, on the other hand, will tell us not only that the benevolent person will tend to do actions that benefit others, for example, but that he will be in some way sensitive to such actions, will have patterns of desire to help others, and will take pleasure in so doing. Insofar as one is concerned with the virtues, the psychological states of the agent are of central importance. As Aristotle says, "the virtues are concerned with actions and passions" (NE1104b, emphasis added). ${ }^{8}$

If this is true, then a primary ethical problem becomes apparent. The passions are things with respect to which we are (at least immediately) passive. They are formed and influenced by factors to a large part outside of our control and thus may lead us astray. Aristotle argues that virtue consists in having them in the proper measure:

both fear and confidence and appetite and anger and pity and in general pleasure and pain may be felt both too much and too little, and in both cases not well; but to feel them at the right times, with reference to the right objects, towards the right people, with the right motive, and in the right way, is what is both intermediate and best, and this is characteristic of virtue. (NE1106b)

How do we bring about this balance? For Aristotle, primarily as a matter of habit - through our moral upbringing, and through the practice of doing virtuous acts. Though there is some debate about the exact role that Aristotle thought explicit ethical reflection plays in the formation of virtue and its relation to practical wisdom, it is clear that we can mold our characters, at least to some extent, based on our reflection on the virtues and the good life. In this way, we can bring our passionate responses more in line with reason or with our judgments about how they ought to be.

What has all this to do with dispassion, especially since I've said that virtue

8. All Aristotle quotations are from the Ross translation, which can be found in, e.g., Aristotle (2009).

Ergo $\cdot$ vol. 5, no. 24 2018 
depends on the passions? There are two things to say. The first is just that, as pointed out above, dispassion has never meant a complete lack of passion, at least when that word is taken in its broadest sense. So it must mean, at the very least, getting rid of bad passionate responses. And this is what is involved in becoming virtuous. In the Stoic tradition, Zeno, for example, defines passion in the much narrower sense as "an irrational movement of the soul contrary to nature, or as an excessive impulse" (SVF 3.412 in von Arnim 1903-1905). Likewise, Clement of Alexandria, perhaps the most Stoic of the early Christian intellectuals, defines passion as "an impulse that exceeds reasonable limits" (Stromateis 2.13.59). If we decide to use the word "passion" in this narrower sense as an affective response that is excessive or contrary to reason, then making one's responses moderate and in accordance with reason, which is part of at least Greek thinking about virtue, seems to be by definition dispassionate.

There is another, slightly more substantive, way that acquiring virtuous habits may deserve to be thought of as part of dispassion. This has to do with the reflective element required for the highest level of virtue. Though our desires and emotions are not directly under our own control, we can, through attentiveness and long practice, bring them into line with how we judge they ought to be. The perfectly virtuous person always and only has the emotions and desires that he thinks he should, when he thinks he should have them, and he has played some active role in coming to be in this state. And so in such a case it seems that he has, at least in part through his own activity, brought his passions under his control in some important respect. In that respect, we can say that he is no longer passive with respect to them - they align, in part through his own effort, with his judgment of how he ought to feel-and thus they are in some sense not really "passions."

I have focused here on the Greek conception of virtue, most obviously exemplified by Aristotle, because of its likely familiarity and its influence on the Stoic and Christian sources that I appeal to in the next section. But the key point for understanding this aspect of dispassion - that "passion" sometimes functions as a technical term for those feelings or emotions that are inconsistent with virtue, even while the virtuous person is subject to other feelings or emotions-applies to other traditions as well. As mentioned earlier, Buddhism famously puts "desire" at the root of suffering and praises equanimity, but these claims have to be interpreted in a way consistent with also accepting as virtues things like effort, compassion, and generosity. When they are, we can see that they must be functioning as technical terms.

\subsection{Dispassion and the Inner Life}

Though the defender of dispassion as an ethical ideal may look at virtue and its development in a distinctive way, if the above was the whole picture, then I don't 
think it would constitute a really distinctive ethical viewpoint. For example, if "passion" just picks out those states which go beyond what reason would allow, then Aristotle (and pretty much everyone else) would count as being an advocate of dispassion. This sort of consideration apparently led Aquinas, following Augustine, to claim that the difference between the Stoics and the Aristotelians was merely verbal. 9

But I don't think this is quite right. I think that the Stoics share a distinctive ethical view with the other traditions mentioned at the beginning of the paper, and that the foundation for this view is an increased focus on the inner life. And I think this focus accounts for the connection, which can be found to some extent in all of the traditions, between dispassion and mindfulness and practices of contemplation and meditation. ${ }^{10}$ Matters become more complex here, but I'll try to sketch out what I see as the connections.

The starting point in the formulation of dispassion as an ideal is an increased focus on the inner life and the phenomenology of the passions, what can be called "the inward turn." It is not hard to see why this focus might have developed. As illustrated above, any virtue-theoretic approach to ethics is going to have something to say about the psychological life of the agent. If this is true, then a reflective agent who is concerned with living a good life must pay some attention to his own inner world, to the workings of his mind. In particular, he must pay attention to those passions which are taken to be against reason or nature and which threaten to hinder his quest for happiness and a good life. This increased attention involves, I think, a discovery which is central to the distinctiveness of views which see dispassion as a primary moral ideal - the discovery that the "bad" passions share something in common besides simply being inconsistent with virtue, which in turn both helps us to identify them and provides strategies for eliminating them.

The different traditions go on to specify the problematic aspects of the passions, and thus to classify them, in different ways. But I think they can all be seen as agreeing in thinking that the passions in this narrow sense involve and give rise to a distorted point of view, that this point of view has to do with some

9. "Aquinas takes his account of dispassionate passions to improve on the Stoics (Sum. Theol.1azae59.2). While arguing for Aristotelian moderation, rather than Stoic extirpation, of the passions, Aquinas approvingly cites Augustine's view that the Stoics differ only verbally from Aristotle, as can be seen from their endorsement of dispassionate passions. Proof that the difference is merely verbal is found in calling only inordinate affections 'passions': then Aristotle also holds that they are not to be found in the virtuous person. The Stoics, Aquinas charges, failed to distinguish the passions from other human affections, and so conflated pseudopassions with passions, not keeping the sensitive appetite distinct from the intellective appetite" (King 2012: 25).

10. In Carey (2018), I discuss these connections and the "inward turn" mentioned as being central to the concept of "spirituality", and discuss how this concept is related to religion. 
distorted relation to the self, and that getting rid of this point of view is necessary for virtue and happiness.

This element of distortion and its relation to the self is perhaps most clear in the case of Buddhism. On the most straightforward reading of the Buddhist view, the passions all involve some strong lust or craving, and this craving is in turn the cause of all suffering. The source of the problem with the class of bad desires is a metaphysical mistake - we think of the self as a simple persisting entity, whereas it is no such thing. The secret to ridding ourselves of passionate attachments is to recognize and be mindful of this mistake, since they presumably cease to make any sense or have any appeal for us once we do. As the Buddha says in one of the Pali scriptures, "Form, monks, is not self .... . Feeling is not self ... . Perception is not self ... [ [Mental] fabrications are not self .... Consciousness is not self . . . . Seeing thus, the well-instructed disciple of the noble ones grows disenchanted .... Disenchanted, he becomes dispassionate. Through dispassion, he is fully released . . . He discerns that Birth is ended, the holy life fulfilled, the task done" (Pañcavaggi Sutta: Five Brethren, SN 22.59, 2013).

On the Stoic account, the problem with the passions is also their relation to a false judgment, though for them this judgment is typically taken to partly constitute, or in some sense just to be, the passion. ${ }^{11}$ In saying that a passion is or involves a judgment, the Stoics need not be denying that there is also a distinctive phenomenology and tendency to action involved. But these aspects are closely related to the cognitive element. To see the connection, think of the contrast between having a reasonable wish for something and lusting after it, or a cautious avoidance of something and being overcome with fear. The latter of each pair clearly involves a distinctive phenomenology, a sort of all-consuming focus of attention and very strong felt desires. But there are also distinctive sorts of thoughts involved, either explicitly in the desires or as things we posit to help explain them. At the very least, what one lusts for is considered good and what one is afraid of is considered bad. However, a simple thought that the desired pleasure is merely a good or what is feared is in some way bad does not fit very well with the consuming, frenetic, nature of the passions. To make sense of what a passion is like, then, the Stoics say that, in being in the grip of a passion, one not only judges that getting what one is pursuing is good or avoiding what one fears is bad, but that it is overwhelmingly good or bad in the situation, the object

11. The best way to understand the Stoic approach to the passions is controversial, in part due to the fragmentary nature of the early evidence, and in part due to the difficulty many interpreters (ancient and modern) have in being sympathetic. Two sympathetic treatments I have found helpful are Long (2006) and Irwin (1998). My discussion here is a sort of synthesis of their presentations. For a longer and more complex treatment showing how various Stoics differed among themselves, see Sorabji (2000). 
of one's passion is somehow normatively essential. One might say, with some plausibility, that the relevant phenomenology is just what really making such an uncompromising judgment is like.

And this is precisely what the Stoic thinks is the primary problem with the passions: they involve attributing an ultimate value to things which do not really have that value. As Irwin puts it, they involve an "uncompromising attachment" to things which are not actually necessary for one's good. The only ultimate good is virtue, and virtue is something that is completely within one's own control at all times. It is in this sense that the sage is self-sufficient-he recognizes that the only thing he really needs in order to have a good life is completely within his control, and so he is in that sense detached from pleasures and pains, from relationships, and even his own life. It is not that he does not care for these things, he just does not uncompromisingly attach himself to them-he accords them their proper worth as subordinate aims of life. Here we see another connection between the passions and the self. For the Buddhist, the passions are those things which depend on a false metaphysical view of the self, for the Stoic, they are those things which involve a false view of what the self needs in order to be good and happy.

Both of these understandings of the passions and what is wrong with them seem to me distinctive and defensible. They help us to isolate a class of passions which have no role to play in the best life, and give us the resources to think about and categorize them, as well as how to begin to defeat them (a point to which I will return below). There is a sense, however, in which they may seem to be based on concerns that are less than completely moral. In the first place, the problems seem to be primarily theoretical. In the second, they each depend on substantive and controversial claims. The Buddhist approach obviously depends on a very controversial metaphysical claim about the nature of the self. The Stoic approach, though not depending on a controversial metaphysical claim, can still seem to be too self-centered, since it makes ethical action seem primarily to be a matter of self-protection rather than a concern for others. There are, of course, ways that defenders of each approach could address these worries, but, in any case, I think that the understanding of the passions that developed later in the spiritual writings of eastern Christianity have a more directly ethical concern.

Though the Christian monastics which I'll focus on inherited much from the Stoic understanding of the nature of the passions, what they found problematic about them was not so much that they involved any theoretical mistake about the self or what it requires for happiness, but rather that they involve a blinding intrusion of the self into thought and action. The mistake, in other words, is not one about the ego, but the more straightforwardly moral problem of egotism. Like the Stoics (as well as the Buddhists and others), the eastern Christians developed various categories and hierarchies of the passions. According to one 
hierarchy which comes up repeatedly, there are three basic passions: pride, lust, and greed. ${ }^{12}$ For example, the fifth century St. Mark the Ascetic says that "the intellect is made blind by these three passions: avarice, self-esteem, and sensual pleasure" (Palmer et al. 1979-1995: Vol 1., 117). The seventh-century St. Maximus the Confessor picks out the same three, but he also makes explicit the crucial connection to the self: "Self-love ... is the cause of all impassioned thoughts. For from it are produced the three principle thoughts of desire; those of gluttony, avarice, and self-esteem ... All the rest ... are consequent upon one or the other of these three" (Palmer et al. 1979-1995: Vol. 2, 92). ${ }^{13}$

We see from these quotes two essential things about these passions, or "impassioned thoughts," as St. Maximus calls them. The first is that a primary problem with them is that they cause a kind of blindness. The idea seems to be this: when we are caught in the grip of the passions of greed, pride, or lust, we have a tendency to value and pay attention to things only insofar as we can own or control them (greed), or insofar as they make us look good to others or feel good about ourselves (pride), or insofar as they give us some sort of pleasure (lust or gluttony). This is a type of blindness because it keeps us from seeing the true nature and value of things or people around us - we only recognize them, if we are not just lost in our own fantasy world, insofar as they can do something for us. And this leads to the second point, made clear by St. Maximus, that the root of this blindness is egotism, that is, inordinate self-love.

One interesting thing about this particular understanding of the passions is that some recent philosophical work has come to a similar conclusion. For example, the importance of attention and the blinding tendencies of an ingrained self-centeredness are central aspects of Iris Murdoch's writings about ethics. She says, for example, that "the chief enemy in morality is personal fantasy: the tissue of self-aggrandizing and consoling wishes and dreams which prevents one from seeing what is there outside one," and that to get around this problem we need to cultivate "a just and compassionate vision, with a clarity which does not belong to the self-centered rush of ordinary life" (Murdoch 1970: 57, 63).

If the passions involve a distorted view of, or focus on, the self, then humil-

12. Occasionally the exact words used differ, though the passions are the same, or very closely connected - for example "self-esteem" rather than "pride," "avarice" rather than "greed," and "pleasure" or "gluttony" rather than "lust."

13. St. Maximus's older contemporary, St. Thalassios the Libyan also makes this connection clear: "Self-love precedes all the passions ... The three most common forms of desire have their origin in the passion of self-love. These three forms are gluttony, self-esteem, and avarice. All impassioned thoughts follow in their wake" (Palmer et al. 1979-1995: Vol. 2, 324). It is perhaps strange in the contemporary climate to think of "self-love" as a vice. The vice of self-love is explicitly connected for St. Maximus and other Christian monastics with an excessive concern with bodily and temporal things - in particular, with one's desires for pleasure, fame, etc. As I say below, I think the best contemporary translation of this vice is egotism. 
ity would seem to be an important virtue. It is perhaps for this reason, that St. Anthony calls it "the first of all the virtues" (Palmer et al. 1979-1995: Vol. 1, 341). Nicolas Bommarito (2013) has recently defended an account of humility which seems almost perfectly fitted to be an important antidote to the passions. He claims that humility is a "virtue of attention," a matter of having one's attention directed in certain distinctive ways, away from the self and especially from one's accomplishments or admirable qualities and towards others and what are taken to be objective values.

Or consider Gabriele Taylor's book Deadly Vices (2006), whose central argument can be seen (though this is not her aim) to vindicate two of the general concerns given above which help to motivate the ideal of dispassion; that is, that the passions involve a problematic connection to the self, and that they are in turn responsible for the suffering of that self. She argues, from a secular standpoint, that the "seven deadly sins" of the Christian tradition

were correctly so named, and correctly classed together. Irrespective of their theological background they can be seen to be similar in structure in that the agent's thoughts and desires, while differing in content depending on the vice in question, focus primarily on the self and its position in the world. They are similar also in that in each case they are destructive of that self and prevent its flourishing. (Taylor 2006: 1)

Now, it may be pointed out that she discusses the seven deadly sins as vices, that is, character traits, rather than passions (though of course character traits are partly defined in terms of their relationships to certain types of passions). And above I referred to what were called "impassioned thoughts," and it may be thought that these are not exactly the same as passions, either. But they are all closely related. In fact, the originator of what became the western tradition of the seven deadly sins, the fourth century monk of the Egyptian desert Evagrius, originally gave a list not of vices, but of logismoi, "thoughts." ${ }^{14}$ These thoughts are connected to the passions by being their necessary causes - they are sometimes referred to as "provocations."

The idea seems to be that passions are always a responsiveness to something thought or perceived. For example, we only become resentful (the sort of anger Taylor thinks of as being a deadly vice) when we remember some wrong that was done to us. Lust flares up in response to some perception or mental image. Pride when we think of our accomplishments or compare ourselves to others. And so on. In some sense these thoughts are "impassioned" simply because

14. See, e.g., On the Eight Thoughts, in Evagrius of Pontus (2003). 
they almost always come into our consciousness without our will or consent. But more importantly, they are the gateways to passions and then to the vices characterized by those passions. They have a certain inertia towards the sorts of emotions and desires which are inconsistent with virtue.

In fact, this focus on attention and the way that the passions misdirect it is a key part of all the traditions. So far in my discussion, I have focused mostly on the problematic content of the passions in each tradition. But the ethical difficulty arises in part also because of the fact that the passions are passions, that is, things with respect to which we are passive. The problem, in other words, is that if we are not careful, we will simply find ourselves fixating our attention on things which depend on a false or inflated sense of self. It is because of this that all of the traditions in which dispassion is an ethical ideal have a corresponding emphasis on something like mindfulness or watchfulness, what is called in the Orthodox (i.e., eastern Christian) tradition "guarding the heart." It is only through watchfulness of our thoughts that we can cut off the passions at their roots. ${ }^{15}$

What is this watchfulness or mindfulness? ${ }^{16}$ It is most of all attentiveness. The basic problem of the passions and passionate thoughts is that they direct our gaze towards ourselves or towards things-as-they-relate-to-our-interests and that this blinds us to other aspects of reality. It seems then that a double attentiveness is needed-we must try to pay attention to the world, to what is at hand as it really is, and we must pay attention to our own minds, knowing how easily unforeseen thoughts can lead to passionate attachments. ${ }^{17}$

For this reason, both Buddhist and Christian texts portray the thoughts of the mind as wild animals capable of wreaking havoc, and claim that preventing this tendency of inattention and scatteredness is a necessary condition for developing virtue. The eighth-century Indian Buddhist monk Shantideva says:

Without [a] guard upon the mind, no discipline can ever be maintained.

Wandering where it will, the elephant of the mind, will bring us down to

15. Several of the writers of the Philokalia discuss the multiple stages involved in the passions, and what can be done at each stage to escape them. For example, according to St. Philotheos of Sinai, there are four distinct stages: "First there is provocation; then a coupling with the provocation; then assent to it; then captivity to it; then passion, grown habitual and continuous" (Palmer et al. 1979-1995: Vol 3., 29). According to St. John of Damascus, there are seven important terms: "provocation, coupling, wrestling, passion, assent (which comes very close to performance), actualization and captivity" (Palmer et al. 1979-1995: Vol. 2, 338).

16. "Mindfulness" is a rather vague term and can mean many things, both as a technical term in Buddhist philosophy and in colloquial usage. As indicated here, I'm thinking of it as a sort of conscious and conscientious attending to the world or one's inner life; I think this captures at least a key part of the idea in its popular and technical usage.

17. For a more detailed discussion of how this double-layered attentiveness might work, see the discussion in Shun (2014) of the Confucian notion of equanimity. 
torment ... If, with mindfulness' rope, the elephant of the mind is tethered all around, our fears will come to nothing, every virtue drop into our hands. (2006: 61)

Remarkably similar claims are made in the writings of the Philokalia. St. John of Karpathos, for example, gives an allegorical interpretation of a biblical story depicting the attack of the "children of the east" by saying that "their "numberless camels' are impassioned thoughts. These hostile armies 'destroy all the produce of the earth', that is, every good action and state" (Palmer et al. 1979-1995: Vol 1., 304). And according to St. Hesychios the Priest,

Just as a man blind from birth does not see the sun's light, so one who fails to pursue watchfulness does not see the rich radiance of divine grace. He cannot free himself from evil thoughts, words, and actions ... As soon as [an impassioned thought] appears in our intellect, our own thoughts chase after it ... Watchfulness is a way of embracing every virtue, every commandment. It is the heart's stillness and the guarding of the intellect. (Palmer et al. 1979-1995: Vol 4., 163)

Though not as exactly corresponding, something similar seems to be expressed about the connection between watchfulness and virtue in other traditions as well. For example, according to the Stoic Epictetus, the sage "keeps watch over himself as over an enemy lying in ambush" (Enchiridion 48.3$).{ }^{18}$ The point of these quotations has been to show that, in spite of a disagreement in detail about the nature of the passions and virtue, those traditions in which dispassion plays an important role have a striking agreement about the general problem the passions present and the primary role of attention in remedying it. These similarities in turn lead to two other commonalities.

The first is the use made in all of these traditions of "spiritual practices" of meditation, or certain kinds of prayer. Though such practices play several roles and differ in emphasis among the traditions, one thing that is shared among them is the involvement of conscious attention and the role such practices play in increasing the ability of the practitioner to remain mindful and attentive, and

18. In still other traditions, Laozi describes the sage as "Watchful, as one who must meet danger on every side. Ceremonious, as one who pays a visit ... Blank, as a piece of uncarved wood; yet receptive as a hollow in the hills" (Lao Tzu 1997: 15). And according to the Confucian author of the Doctrine of the Mean (2013), in order to cultivate the Way and keep the emotions in harmony, "the Superior Man is cautious in the place where he is not seen, and apprehensive in the place where he is not heard ... Therefore the Superior Man is cautious even when alone." The translation of this passage varies widely across versions. In conversation, Kwong-loi Shun has said that the last part could perhaps best be translated "the Superior Man is watchful over what he alone knows", i.e., over his inner life. 
thereby to positively affect the way that they see the world. There might seem initially to be a paradox involved in the attempt to become dispassionatesubjection to the passions indicates a lack of active attention to the right sorts of things, but the only way to avoid such subjugation is through attention, and that is the very thing that is lacked. The solution, at least in part, is to practice paying attention. This is in part what all the contemplative practices of the various traditions involve-a deliberate focusing of attention on the breath or a mantra (in some forms of Buddhist meditation), or on the presence of God or the divine name (in some forms of Christian contemplative prayer), or on accepted philosophical doctrines and the proper way to respond to various possible scenarios (in some forms of Stoic exercise). Like a mental muscle, the more attention is deliberately focused, the higher the capacity for attention becomes. ${ }^{19}$

The second commonality is in the ideal of the sage or saint. Although there will again by many differences in the details of how such a person is conceived among the traditions, there remains a striking similarity. In each tradition, the virtuous person is conceived as an exemplar with a certain distinctive style. The sage is characterized by a noticeable tranquility and inner peace, a relative lack of anxiety or fear. Though in a way detached from material concerns, in another way they will seem more engaged than others, more attentive to their surroundings and work. Finally, they will be characterized by humility and compassion and an increased sense of the connectedness of things.

These characteristics arise from the second, and really distinctive, aspect of dispassion - the watchfulness of the inner life, the refusal to be dragged around by the "elephant of the mind," and the attempt to cultivate a "just and compassionate vision" of reality. Both aspects of dispassion, as I've argued here it should be understood, are nicely summed up by the $11^{\text {th }}$ century saint Nikitas Stithatos:

Dispassion is of two kinds and takes two main forms . . . They attain the first kind of dispassion when they have become adept in the practice of the virtues ... Subsequently ... they attain in their wisdom the second and more perfect kind of dispassion. Bringing inner stillness to their thoughts, this dispassion raises them to a state of intellectual peace. (Palmer et al. 1979-1995: Vol. 4 103) ${ }^{20}$

19. Contemporary science has shown the ability of certain forms of "mindfulness meditation" to do just that. See, inter alia, the references in the next section.Contemporary science has shown the ability of certain forms of "mindfulness meditation" to do just that. See, inter alia, the references in the next section.

20. The great Neo-Confucian scholar Zhu Xi seems to have something very similar in mind when he talks about the combination of "righteousness" and "inner mental attentiveness":

To nourish yourself, you must practice inner mental attentiveness. To manage affairs, you must accumulate righteousness ... Inner mental attentiveness and righteousness are simply one matter. It's like our two feet: firmly planted they are inner mental attentiveness, but as soon as they move they 


\section{The Appeal of Dispassion}

In the previous section, I tried to show that there is a distinctive ethical approach involved in conceiving of the virtuous person as dispassionate, and that there is a basic structure to such a conception that is shared by several ancient ethical traditions. I hope also to have shown that the conception can be made sense of while bracketing the more general metaphysical and theological backgrounds of those traditions, as well as something of the appeal of the ethical ideal of dispassion. I want to finish by saying some further things about its appeal. In particular, two things seem to me especially appealing. The first is the way that it both goes beyond typical ethical theories while also unifying the moral life. The second is the way that it opens up practical avenues towards personal improvement.

In some sense, making out the former was the partial aim of the whole previous section, so here I will just briefly restate what I take to be the upshot. One advantage of virtue ethics is that it concerns itself with the person rather than with actions considered in the abstract. It also sees the emotions and desires of the agent as at least as ethically important as his actions, and (in part because of this) directs our attention towards the difficulty of moral training. For these reasons, it has seemed to many as a more attractive and holistic approach.

If my treatment of them has been correct, then the traditions which have an ethical ideal of dispassion go two steps beyond these general advantages of virtue ethics. In the first place, they all go beyond the mere recognition of the ethical centrality of our passionate responses. They pay sustained attention to our inner lives in order understand how the mind functions and how best to bring about positive changes. And, at least according to the three traditions I've discussed (though there is some disagreement in the details), there is a single problem at the root of all of our ethical problems, at least where our emotions and desires are concerned: a disordered relationship to the self which keeps us from seeing reality as it is. If true, this provides a helpful way of unifying our ethical concerns and relating them to one another.

It also helps, and here I move on to the second main source of appeal, to provide a target for our strategies for ethical improvement. As I've said, these traditions not only recognize a similar problem underlying our negative emotional reactions, but they also have strikingly similar strategies for dealing with the problem: detachment, mindful attention, meditation, contemplative prayer or study, etc. While differing in various respects, each of these involves in part an effort to regain control of one's attention and direct it in certain helpful ways.

are righteousness. Or our eyes: when closed, they are inner mental attentiveness, but open and looking at things they are righteousness. (Zhu Xi 1990: 175)

Ergo •vol. 5, no. 24 2018 
If these strategies work, they hold out the possibility for improving our lives and reducing unnecessary mental suffering.

Whether they do work is in part, of course, an empirical matter. But recent empirical work seems to give us good grounds for optimism. Positive psychology's recent interest in mindfulness, which I've argued is an essential part of achieving dispassion, has shown in many ways the positive effects of attempting to cultivate increased attentiveness. On the one hand, it has been shown that, in the title of a well-known article, "A Wandering Mind is an Unhappy Mind" (Killingworth \& Gilbert 2010). On the other, it has been shown that, inter alia, mindfulness meditation increases cognition and mood (Zeidan, Johnson, Diamond, David, \& Goolkasian 2010), attention span (Valentine \& Sweet 1999), and efficient moral reasoning and decision making (Shapiro, Jazaieri, \& Goldin 2012). ${ }^{21}$

In addition, while studies on "happiness" connect it with mindfulness and attention to the present, others have found that "meaningfulness" is a different thing, one which can come apart from happiness. Meaningfulness seems to depend instead on taking a more reflective standpoint on one's life as a whole and comes along with the sorts of unselfish commitments and virtues that we think of as part of a good life (Baumeister, Vohs, Aaker, \& Garbinsky 2013). ${ }^{22}$ Given these findings, having a life which is both happy and meaningful seems to depend on both reflectively pursuing the virtues and cultivating an ability to be attentive to the present and one's immediate state of mind. And this is just what is involved in dispassion as understood above.

\section{Conclusion}

More work is needed both in the analysis of the central concepts discussed above and in argument about their role in the ethical life. But I hope to have shown that there is a common core to the understanding of dispassion as an ethical ideal in several different traditions, that this core can be understood in contemporary and not explicitly religious terms, and that there is something deeply appealing about the picture that emerges. Part of this appeal, part of what strikes me as the theoretical and moral power of an ideal of dispassion, is in the way that it can bring together and unify many different aspects of the moral life rarely treated by contemporary philosophers. At the very least, these concepts are deserving of more philosophical work than they have so far been given.

21. For a more recent paper which specifically connects meditation to cultivation of virtue, and includes several other relevant citations, see Upton (2017).

22. It is worth noting that Baumeister is one of those most implicated in psychology's replicability crisis, though so far as I know his work on this particular issue has not been called into question. 


\section{Acknowledgements}

For encouragement and inspiration, I am especially grateful to Lara Buchak, David McNaughton, and Kwong-loi Shun. For feedback on earlier drafts, I am grateful to Rico Vitz, my colleagues at Siena College: Joshua Alexander, Jennifer McErlean, Raymond Boisvert, John Burkey, Paul Santilli, and Anthony Manela, and to two anonymous referees.

\section{References}

Aristotle (2009). The Nicomachean Ethics (David Ross, Trans.). Oxford University Press.

Baier, Annette (1986). The Ambiguous Limits of Desire. In Joel Marks (Ed.), The Ways of Desire (39-61). Precedent.

Baumeister, Roy F., Kathleen D. Vohs, Jennifer L. Aaker, and Emily N. Garbinsky (2013). Some Key Differences between a Happy Life and a Meaningful Life. The Journal of Positive Psychology, 8(6), 505-516.

Bommarito, Nicolas (2013). Modesty as a Virtue of Attention. The Philosophical Review, $122(1), 93-117$.

Carey, Jeremiah (2018). Spiritual, but Not Religious? On the Nature of Spirituality and Its Relation to Religion. International Journal for Philosophy of Religion, 83(3), 261-269.

Davis, Leesa S. (2014). Mindfulness, Non-Attachment and Other Buddhist Virtues. In Stan van Hooft (Ed.), The Handbook of Virtue Ethics (306-317). Acumen.

Dixon, Thomas (2011). Revolting Passions. Modern Theology, 27(2), 298-312.

Evagrius of Pontus (2003). The Greek Ascetic Corpus (Robert E. Sinkewicz, Trans.). Oxford University Press.

Frakes, Chris (2007). Do the Compassionate Flourish?: Overcoming Anguish and the Impulse Towards Violence. Journal of Buddhist Ethics, 14, 99-128.

Irwin, T. H. (1998). Stoic Inhumanity. In Juha Shivola and Troels Engberg-Pedersen (Eds.), The Emotions in Hellenistic Philosophy (219-241). Springer Netherlands.

Killingsworth, Matthew A. and Daniel T. Gilbert (2010). A Wandering Mind Is an Unhappy Mind. Science, 330(606), 932.

King, Peter (2012). Dispassionate Passions. In Martin Pickave and Lisa Shapiro (Eds.), Emotion and Cognitive Life in Medieval and Early Modern Philosophy (9-31). Oxford University Press.

Lao Tzu (1997). Tao Te Ching (Arthur Waley, Trans.). Wordsworth Editions.

Long, A. A. (2006). Epictetus on Understanding and Managing Emotions. In From Epicurus to Epictetus: Studies in Hellenistic and Roman Philosophy (377-394). Oxford University Press.

Marks, Joel (1995). Dispassion and the Ethical Life. In Joel Marks, Roger Ames, and Robert C. Solomon (Eds.), Emotions in Asian Thought (139-159). State University of New York Press.

Moss, Jessica (2012). Aristotle on the Apparent Good: Perception, Phantasia, Thought, and Desire. Oxford University Press.

Murdoch, Iris (1970). The Sovereignty of the Good. Routledge Kegan Paul. 
Olberding, Amy (2007). Sorrow and the Sage: Grief in the Zhuangzi. Dao: A Journal of Comparative Philosophy 6(4), 339-359.

Palmer, G. E. H., Philip Sherrard, and Kallistos Ware (Eds.) (1979-1995). The Philokalia: The Complete Text (Vols. 1-4). Faber and Faber.

Pañcavaggi Sutta: Five Brethren (SN 22.59) (2013). Bikkhu Thanissaro (Trans.). Retrieved from http://www.accesstoinsight.org/tipitaka/sn/sn22/sn22.059.than.html

Shantideva (2006). The Way of the Bodhisattva (The Padmakara Translation Group, Trans.). Shambhala.

Shapiro, Shauna L., Hooria Jazaieri, and Philippe R. Goldin (2012). Mindfulness-Based Stress Reduction Effects on Moral Reasoning and Decision Making. The Journal of Positive Psychology 7(6), 504-515.

Shun, Kwongloi (2014). On Reflective Equanimity: A Confucian Perspective. In Chenyang $\mathrm{Li}$ and Peimin Ni (Eds.), Moral Cultivation and Confucian Character: Engaging Joel J. Kupperman (127-150). State University of New York Press.

Sorabji, Richard (2000). Emotion and Peace of Mind: From Stoic Agitation to Christian Temptation. Oxford University Press.

Stace, Walter T. (1952). Oriental Conceptions of Detachment and Enlightenment. Philosophy East and West (2)1, 20-30.

Staniloae, Dumitru (2003). Orthodox Spirituality: A Practical Guide for the Faithful and a Definitive Manual for the Scholar. St. Tikhon's Seminary Press.

Symeon the New Theologian (1995). On the Mystical Life: The Ethical Discourses by Symeon the New Theologian (Alexander Golitzin, Trans.). St. Vladimir Seminary Press.

Taylor, Gabriele (2006). Deadly Vices. Oxford University Press.

The Doctrine of the Mean (2013). Muller, A. Charles (Trans.). The Doctrine of the Mean. Retrieved from http://www.acmuller.net/con-dao/docofmean.html

Upton, Candace (2017). Meditation and the Cultivation of Virtue. Philosophical Psychology $30(4), 373-394$.

Valentine, Elizabeth R. and Philip L. G. Sweet (1999). Meditation and Attention: A Comparison of the Effects of Concentrative and Mindfulness Meditation on Sustained Attention. Mental Health, Religion and Culture 2(1), 59-70.

von Arnim, Hans (1903-1905). Stoicorum Veterum Fragmenta. Teubner.

Wong, David B. (2006). The Meaning of Detachment in Daoism, Buddhism, and Stoicism. Dao: A Journal of Comparative Philosophy 5(2), 207-219.

Zeidan, Fadel, Susan K. Johnson, Bruce J. Diamond, Zhanna David, and Paula Goolkasian (2010). Mindfulness Meditation Improves Cognition: Evidence of Brief Mental Training. Consciousness and Cognition 19(2), 597-605.

Zhu Xi (1990). Learning to Be a Sage: Selections from the Conversations of Master Chu, Arranged Topically (Daniel K. Gardener, Trans.). University of California Press.

Zhuangzi (2003). Zhuangzi: Basic Writings (Burton Watson, Trans.). Columbia University Press. 
